\title{
Working Together with South Saami Birth Stories - A Collaboration Between a Saami Midwife and a Saami Researcher
}

\author{
Åsa Virdi Kroik, Jonhild Joma
}

\begin{abstract}
This paper presents some results from a community-based project among local South Saami in the Norwegian and Swedish part of Saepmie. I was co-coordinating a two-year community-sponsored project in the community (Røyrvik) in which a local South Saami midwife documented stories from elder Saami about childbirth in earlier times, both from their own memories and from stories they knew. Her work became an article in a book, and the project helped us to understand much more about childbirth and general living conditions for Saami one to three generations ago in this area. As a $\mathrm{PhD}$ candidate, I have complemented her work with a theoretical framework (Indigenous Research Methods, colonial perspective), a historical analysis, and a contemporary context. Apart from presenting an example of stories she was given and how they can give us new knowledge. But I will focus on the meanings, processes, theories and practices of engaged Indigenous community research. I will describe our different methods and the benefit of working together and will point out how it will further research.
\end{abstract}

KEYWords methodology; Saami people; revitalization

This article is about Saami practice and Saami attitudes to pregnancy and child-birth in an area of South Saepmie (Norway and Sweden). It is also an article about stories, and how to be able to use stories as a successful tool among the colonized and silenced south Saami people, when documenting Saami oral tradition and Saami holistic epistemology. It is also a step toward a research methodology that equalizes the power relation between the researcher and the researched.

Angela Cavender Wilson states in "American Indian History or Non-Indian Perceptions of American Indian History" (1998) that "American Indian History is a field dominated by white, male historians who rarely ask or care what the Indians they study have to say about their work. Under the guise of academic freedom they have maintained their comfortable chairs in archives across the country and published thousands of volumes on white's interpretation of American Indian history" (Wilson, 1998, p. 23).

The statement is valid for the Indigenous people, the Saami, in Saepmie ${ }^{1}$ the regional home of the Saami of Norway, Sweden, Finland, and Russia as well. Saami have been unable

\footnotetext{
1 The word Sápmi is the more well-known north Saami name of the same region.
} 
to influence their written history until recently (Lehtola, 2004, pp. 34-35). We must also take into account that the majority of the Saami researchers with power to influence historic writing, as well as the majority of Saami in other power positions in the dominating society, belong to the regional, cultural and linguistic majority of the Saami-the north Saami. That means that voices of the south Saami people, as a minority within the minority, struggle with more difficulties to make themselves heard. Local areas in the south of Saepmie are thus more vulnerable to oppressive power. Such an area is Frostviken/Namdalen, the area focused on in this article.

Royrvik is a community situated in the southern part of Saepmie, on the Norwegian side, in Nord-Trondelag, neighboring Jämtland district to the east, on the Swedish side. The community is inhabited by approximately 500 people, of which $10 \%-20 \%$ are believed to be Saami. It is a part of a culturally coherent area that I call Frostviken-Namdalen in Norwegian and Swedish, as it has no name in Saami language.

From a south Saami perspective, this region is among the most culturally strong and significant areas, as many Saami have their origin here. Among them are important and powerful persons in south Saami history, such as Ella Holm Bull (1929-2006) a preserver of the Saami language, who produced a considerable amount of educational literature and music in south Saami, and was an initiator of, and for a couple of years the principal of, the Saami school Åarjel saemiej skuvle (Hermanstrand, 2009, p. 345).

The geographical area of the Røyrvik community was colonized rather late in Norwegian history. Colonization, with the mining and the building of dams in the 1950s, dramatically changed the daily life of the reindeer-herding Saami in the Røyrvik area. Reindeer herding was disturbed, for instance, by the damming of the lake Namsvatn, where a whole village was submerged and had to be rebuilt in a new place (Jürgensen, Svestad, and Fiskum 2013, pp. 93-94). Many lakes are believed to be sacred among the Saami, and the lake name Namsvatn implies that this might be the case. Place names surrounding the lake also indicate that it was likely a sacred site (Virdi Kroik 2010). These things are rarely talked about in public among the Saami themselves and are studied with difficulty in the contemporary south Saami society. As is the case with many other Indigenous peoples, Saami are often described as silent (Svestad, 2013, p. 57; Devy, 2006, p. 55; Dahl, 1940, p. 192; Mihesuah, 1998).

The Saami's traditional reindeer-herding economy is vital in today's society and an important sector of the economy, an economic force that cannot be neglected by community politicians. There have been and, and still are, strong ties between the Saami on the Norwegian side and those on the Swedish side. The national border was delineated in 1751 and split a coherent traditional Saami area in two-yet another trauma of many, in the history of the south Saami people. However, it never completely divided the Saami people who were connected by intermarriage, genealogy, culture, economy, and a common history (Virdi Kroik, 2007, pp. 29-30). Nevertheless, the Saami have been culturally influenced by the nation state they are members of, and by its dominating culture. That is evident, for instance, in their first language which is often, although not always, that of the national majority. Still, they suffer from being made invisible in history, and neglected in many other ways. 
The Saami have been victims of an aggressive Christian mission, especially during the eighteenth century when a number of Saami were sentenced to death for using their traditional drums. When the national states of Sweden, Norway, Denmark, Finland and Russia were competing for access to territory and the right to tax the inhabitants in the northern geographic areas, the Saami became pawns; their territory, their resources, and their independence were taken over by the colonizers, who re-organized the Saami ways of living (Bäckman, 2013, pp. 11-22; Rydving 1993).

During the last hundred years, the Saami had to face two destructive state policies: one used mainly by the Norwegian state and called förnorskningspolitiken, was designed to assimilate the Saami into the dominating culture; and the other, used mainly by the Swedish state and called lapp ska vara lapppolitiken took the opposite position and focused on separating the Saami from the majority culture and preserving them from outside influence as much as possible. The two policies have sometimes been used at the same time, and can still be seen in active use, in different ways by the two political states.

The situation for the Saami was also strongly affected negatively, by two influential academic theories and schools. The first was race biology that had its starting point in Charles Darwin's The Origin of Species (1859). Darwin's theory of evolution was adapted to Scandinavian conditions by, among others, Anders Adolf Retzius (1796-1860). This scientific school published photographs of naked Saami and other minority groups, taken under humiliating circumstances, pictures that can still be accessed online from Uppsala University. ${ }^{2}$ The other is the historic Immigration Theory ${ }^{3}$ that claimed that Saami had not always inhabited the southern areas they now lived in, when the theory was formed in 1889, but had immigrated there during the $16^{\text {th }}$ century (Hermanstrand, 2007 p.486; Zachrisson, 1997 pp.18-19; Åhrén, 2004 pp.65-67; Dunfjeld-Aagård, 2007 p.53; Lundmark 2004).

Conflicts were intensified between reindeer herders and settlers in Røyrvik during the 1920s and 2000 decades, but were dealt with in a historic theater project called Bruer mellom kulturer ("Bridges Between Cultures"). The project involved an impressive portion of the total inhabitants of Røyrvik community. The traumas caused by the revival of collective memory were dealt with by sharing stories with each other and by together creating the manuscript for the performance of these stories. The participants of the project were also actors and members of the choir with some help from a few professional outsiders. Stories are well suited for Saami epistemology, i.e., its holistic and non-verbal nature, and the project had a calming effect on the increasingly heated emotional climate. There were moments of insight and regret during the work with the project, which were described by some participants as very powerful. Stories are claimed to be a powerful tool in the work of healing historical traumas, as was validated by the results from this project (Jürgensen, Svestad and Fiskum, 2013, p. 94; Episkenew, 2012; Wilson, 1998).

\footnotetext{
2 I don't provide the URL for Uppsala University's homepage where these pictures can be seen online because I don't want to encourage readers to look at the pictures and reproduce the humiliation. Instead I have provided the URL for the Facebook group protesting against Uppsala University for making the photographs available.

3 Framryckningsteorin in Norweigan or Invandringsteorin in Swedish.
} 
I was employed as a coordinator for Saami language and culture by the community of Røyrvik from 2008-2010. A few years had passed since the completion of the theatre project and there was fear that that the contradictions would come back. The racist political party Framskrittspartiet was increasing its number of voters in Røyrvik, just as elsewhere in the country. I heard people ask for the show to be put on again. There were also Norwegian voices recognizing the need for working on a common identity, together with the local Saami within Røyrvik, and stating that the distance between the Norwegian inhabitants and the Saami was too wide. The Saami, on the other hand, had other needs. They had no need for a local identity, but due to the dominating Norwegian influence, they felt culturally and territorially threatened. There was a need among them to have somewhere to go, and to have someone in a position of power to listen to them. My position in the community house meant that there would at least be one Saami representing them there on daily basis. While the norms and structures in society were benefiting the majority, the Saami asked for special activities to revitalize and reinforce their language and culture. My task was to meet the different needs.

Why was I chosen for this task and why did I take on the challenge? My personal story will answer those questions. I grew up in a village in the mountain area on the Swedish side of south Saepmie. My Saami village, sameby, (the term for a specific Saami geographical area and an economic, social and juridical organization) is named Voernese and is a neighbor to Østre Namdal's reindeer-herding district, reinbetesdistrikt, (the equivalent to sameby in Norwegian) in which Røyrvik community is situated. I grew up in a reindeer-herding family. After completing undergraduate studies in one of the closest colleges in the coastal area about $400 \mathrm{~km}$ away from my home village, I moved to the capital of Sweden, Stockholm. I earned a Master's Degree while working in various occupations. It was possible for me to study, thanks to the owner of the room I rented, who charged me very little. I have learned that Saami who are able to take higher degrees in the formal educational system, are often funded by various benefactors. Saami, just as most other Indigenous people, seldom have the means to finance higher formal studies. The opportunity to go back and work in my home area and Røyrvik came after many years as an urban citizen, and after beginning a family. I took my family with me, bought a house, and spent 3 years in an area where most Saami were relatives of mine. Many of them were familiar, although not well known to me, as I had most often met them in situations where the work with reindeer had been at the center. During these three years, we had the privilege to get to know the extended family better.

My theoretical purpose was to empower the most vulnerable segment of society through activities formed in a way they would fit the Saami inhabitant and encourage them to participate in them, and when possible, to make them and their competence more visible to the local community. A strategy often employed by vulnerable groups is to make themselves invisible (Devy, 2006, p. 31). Increased visibility is often thought of as increasing the risk of becoming targets for attacks in the form of hurtful comments, violent attacks on their reindeer, or other expression of racism. Such attacks may not always be consciously or intentionally performed by the attacker (Habel, 2012, p. 46), but they are nonetheless painful for the victims, and a good reason for keeping themselves, their knowledge, and their resources hidden. It's also 
a good reason for grouping together and firmly excluding outsiders. My ambition was to involve all ages and make at least one project for each age group, as I thought the project belonged to ALL Saami in the area. Typically, project workers target the most active, busiest, and most visible Saami, the reindeer herders. Herders are highly visible since they often have to defend their animals and their economic lifestyle, and therefore other Saami voices tend to be neglected.

One project involved two Saami midwives. One of the midwives, Jonhild Joma, wrote an article about her work, included in a book that I published concerning my years in Röyrvik (Joma, 2010). I took advantage of her skill and interest in the topic; she developed the research questions herself. She thought it important to preserve the knowledge about the birth stories and ask elders who had lived through a time of rapid change for the Saami. As Jonhild herself was close to retirement, she was familiar with many of these changes, a great help for accessing very local knowledge. Her concluding remark in her article shows the meaning she found in her work: "For a people that has been exposed to the dominating society's power, it is inspiring to discover that we still get strength in identifying our own culture. We have to take responsibility to preserve our legacy and transfer it to those who come after" (Joma, 2010, p. 84).

Jonhild Joma grew up as a nomad in the reindeer herding district of Østre Namdal. She became a very important person for me as a culture holder with great knowledge in various fields. She also became a very good friend, and we had many enjoyable moments in her kitchen, on journeys, and on tours in nature. Jonhild collected stories. She wrote them in the same style as they were told, often with humor. This is her story of herself and her work in the article she wrote, translated from Norwegian to English by me.

\section{Jonhild Jomas' Story}

I grew up as the youngest of five children. My parents were reindeer herders and our winter pasture was situated west of Geitfjellet. During winter, we lived in a gåetie (traditional Saami tent similar to a teepee) at a place called Snàsaheia which is still a place for reindeer herders on wintertime. In summer, we lived in Jobkegaske in the area of Børgefjell. My siblings were born before the war, two of them at my mother's mother's place and the other at my father's mother's place, both in Røyrvik community. When I was born, we had come into a new era, as my mother expressed it, and she took the train about $170 \mathrm{~km}$ to Namsos where she gave birth to me in a hospital. She was alone at that time. She had given birth to five children and did not want to complain. I was born in December. As an adult, I have thought about how dramatic that the journey home must have been: First we went by train to Brekevvasselv, and from there by horse and wagon in bad

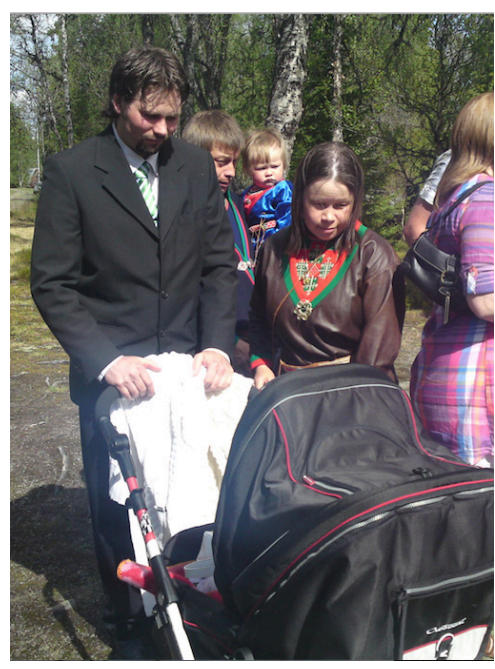

Figure1: Jonhild found a way to collect stories about birth, pregnancy and children - a topic so close to everyday life that it is rarely documented. 
weather over the mountain Steinfjelet to Gjersvika. My father was waiting there with a boat that took us over the lake Limingen to the village Liminglia, where we rented a house.

I was educated as a nurse and continued to study to become a midwife in the city of Bergen in the south east of Norway. In 2003 I participated in a project as the only Saami. It was an interesting theme to work with. When I was asked to work in Åsa's project in 2009, I was inspired to start again. Now I would be freer, and could write about what I wanted. But there was a lack of time. I have talked to ten Saami from the age of approximately around fifty or sixty, to older than ninety. I have talked to both men and women, and all of them told me in the beginning that they didn't know anything. I taped the conversations, but at times people asked me to turn it off, and I considered it necessary. All of them have a connection to Røyrvik, but lived in different places. When I asked and received information, new questions were raised, such as "How did my grandmother know that it would be easier to kneel at beech delivery?" I have asked where the women gave birth. Were more children born in certain times of the year? Who was with the mother and did several people help? Did she lie down when she delivered or did she use another position? If a skin was used, what did they do with it after the delivery? What happened with the placenta? How was the umbilical cord removed? Were there any preparations, like massage, for example, during the pregnancy? Where were elder siblings during the childbirth? Did any mother or child die during delivery or soon after? To what degree was the child-giving woman active after the delivery? Did she get any special attention when she was expecting the child?

\section{Methods and Results}

Jonhild put her energy into talking with Saami and documenting living Saami memories about pregnancy and birth. I'm glad she did so. I, as a younger Saami without her network or experience, would not have been able to do the work she did. I have, though, been able to use her systematization and find relevant information as a complement to hers. As we have already seen, Jonhild used her own mother and herself as sources. She took an interest in the oftendramatic stories and circumstances in which the actual delivery took place. She showed the conflict between the old lifestyle, where birth took place in the Saami's ordinary setting, with the contemporary custom of giving birth in hospitals. The distance to such facilities made the Saami undertake journeys they would not have done in the past.

In one story, the father placed the wife in labor on a toboggan, and hired help for the transport to a midwife. In the forest, they realized that they would not get there in time, so he lit a fire and arranged a place under a tree. After the birth, they went back home, and the woman said that it would have been so much better to stay at home in the first place, instead of being transported to the forest to give birth under a tree (Joma, 2010, p. 80). Many stories show that birth took place in homes. Jonhild concluded that before 1945, most women gave birth wherever they were at that moment, some with their mother or mother-in-law. They did not seem to choose any particular place to give birth; they just sat down to wait for the delivery to begin (Joma, 2010, p. 78). When Harry Kappfjell announced his arrival, the father, Nils Olav, begged his wife Ivara to hold back until they had better time. They were in the middle 
of the autumn slaughter and had no time to get the midwife. Harry could not be convinced to stay inside his mother though, and so he was born there in Ivara's parents house in Graneskogen (Joma, 2010, p. 80).

My colleague Jorunn Jernsletten, who is a north Saami and did her dissertation fieldwork in a neighboring area to ours, was able to collect a story about a woman and her child who died close to a stone that was sheltering them (Jernsletten, 2010, p. 103). Such stones were remembered, and the story was told whenever Saami passed it (Jernsletten, 2010). While working in Røyrvik, I, together with locals, did investigations in the landscape following the stories and memories people gave us. Some of these locals were reindeer herders, while others were farmers. There were also a few Saami who joined while visiting the area and wanted to see their ancestral areas. We went to look at a place where we knew an old Saami woman was born. She was not able to come with us, but together with an archeologist, we found many hearths at the place and other traces showing that it had been an important place for reindeer herding. The river was also shallow and wide there leading us to think that it was a good place for reindeer to pass. Not far from the investigated place, the archeologist was able to find a pit trap, probably of older date.

Children and women had their own spiritual guardians. The most important was Maadteraahka. She was responsible for the creation of human beings and for their protection. Her location in the traditional home, gaetie, was as far away as possible from the fireplace, near the wall. She had three daughters. They helped and supported those who lived in the gåetie. Another guardian, Saar-aahka, had her place under the hearth, close to where the food was. She protected home and family, and was a supporter through childbirth. South Saami professor emerita Louise Bäckman (Stockholm University) has thoroughly investigated Maadter-aahka and her daughters in the old sources and confirms the particular importance of Saar-aahka's role in child delivery (Joma 2010, p.78; Bäckman 2013, pp. 107-116).

As is common among people of all societies, not all infants are healthy and well-formed. Therefore, customs arise whose purpose is to prevent deformities or still births. Jonhild recorded several such practices, although she was unable to judge what people really believed and what had been said just to frighten pregnant women into being careful. It was a common belief that if the mother was pleased during the pregnancy, the child would likewise be easily pleased. On the other hand, a frightened mother could be dangerous for the baby. A pregnant woman should also not see certain animals. A hare could, for example, make the child harelipped. A mouse could be dangerous for two reasons: it could give the baby birthmarks or the mother's startled fright could have consequences for the child's intellect. Jonhild didn't find any information about the pregnant woman's diet, or any listing of foods that should be avoided. However, expectant mothers didn't participate in slaughter and did not use heavy tools like scissors, axe or similar implements (Joma, 2010, pp. 76-77). According to a nineteenth-century source, neither the mother-to-be nor the father-to-be should cut a cow's head, as it might harm the baby (Drake, 1979, p. 237). I was able to find good documentation from this in book. As most documentation and research about the Saami has been done by non-Saami men, such issues are rarely mentioned in their work. 
In many cultures, men are separated from birth-giving and all rituals connected to birth. This is not the case among the Saami. In one case, I heard about a father assisting with the delivery of all his five children. Jonhild found that men were often involved with the act of giving birth, sometimes assisting the wife. Johan Westerfjell, 85 years old, told Jonhild that his mother Elle was born at a gierkie-lihpie, a big sheltering rock.. Mathias, the father, assisted. Everything went fine and afterward Serine, the mother, went to pick berries and milked a reindeer so they would have milk. Nils Mathias, on the other hand, was exhausted and had to take a nap (Joma, 2010, pp. 79-80). Another story recorded by Jonhild concerned a Saami man in the company of several men from the majority culture. While they were together, a young pregnant woman also present went into labor and locked herself in a nearby room, groaning in pain. While the other men uncomfortably avoided the room, the Saami knocked on the door and told her to open because he knew what was going on. He was not afraid to her assist her in the delivery of her first-born. Many of the stories told to Jonhild informed her about how the father transported the woman to get to a midwife or to find shelter when she gave birth, reminding Jonhild about her own mother and her journey to and from hospital. Fathers also took part in burying the afterbirth, which was the custom in the past, and is sometimes even done today. That men were so active in the preparations during women's pregnancies and during delivery was one of the surprises of the study.

One of the oldest written sources, Procopius, from around 550, informs us that as soon as a Saami woman has given birth to a child, she wraps it in a fur and hangs it in a tree. She gives the baby a piece of bone with marrow to suck on and then goes hunting with the men. Feeding babies with marrow is a familiar custom, and the practice of hanging a baby in a tree can be better understood when you know about the gierkeme, a kind of cradle, also used for carrying babies, that is still widely used. Jonhild writes that it was commonly used among her storytellers; one of them even remembered that a bigger one was made when twins were born. She relates that the gierkeme was borrowed, inherited, or made by the father or the grandfather. It was made from a hollowed log, covered with reindeer skin and decorated with ribs and other items. In the bottom guepmie, tinder from a stock or suejnie, hay for shoes was placed. On top of that was placed a reindeer calf's fur. Babies in a gierkeme can be breastfed without being removed from it, and if it is extremely cold, an extra fur can cover the whole gierkeme. It is a good place for babies (Joma, 2010). What Jonhild and I found was that, among the Saami nomads of the previous generations, childbirth was something considered more natural and a part of the ordinary life than it is today. Women gave birth with the help of the family, sometimes the father, and sometimes children. It was common that in-laws helped each other.

\section{Considerations of Meaning, Value, and Theory}

The stories that Jonhild was collecting contained knowledge that is rarely talked about and that seems to have had little value for previous researchers and documenters. Possibly previous researchers did not even have access to such stories as Saami deliberately or unconsciously seem to have excluded outsiders from such information. But Jonhild had access. When she asked for specific memories, the act of asking gave them value. The stories tell us that the south Saami 
had their own attitudes, knowledge, practices and ideas about childbirth that differed from the majority culture and that still characterize their ways of thinking today. The memories of the older times are still alive and could become the subject of future studies, provided that the interviewer is someone who knows what questions to ask, preferably someone who is a part of the group, who is engaged in the traditions.

In the current culture, in Norway and in Sweden, the assertion that the Saami people form a distinct group of people is politically sensitive, as certain political powers claim that there is no difference between them and the majority. In extreme political circles, the statement that the Saami are the indigenous people of Scandinavia is questioned in both Norway and Sweden. Jonhild's study, however, provides a more intimate glimpse of the relations between the Saami and their neighbors. Her stories show that the Saami sometimes were discriminated against by Norwegians; for example, a Saami woman, even in labor, was not permitted into the house of a Norwegian to give birth to her child. Jonhild did not include that information in her article, due to political sensitivities. In this English version, she and I decided that it could be included.

That picture of differences and discrimination is confirmed by the historian Håkon Hermanstrand, who wrote a book about the Røyrvik Saami at the same time as I was working there. In his work, he differentiates between the words samieb (the south Saami word for Saami) and laedtieh (the south Saami word for persons of Non-Saami origin), and notes that even though he has heard many stories of positive relations between the two groups, there are also many Saami stories of conflict, hurtful memories, arrogant attitudes and feelings of unfairness. His intention was not to make new conflicts, but neither was it to deny what has happened (Hermanstrand, 2009, p. 11). Jonhild likewise confirmed the existence of positive relations by pointing out that Saami women were appreciated for their skill in helping women to give birth. She also mentioned that it was common for a house owner, often a Norwegian or Swede, renting out room for nomadic Saami when passing with the reindeers, to be asked to become godparent to a newborn Saami child (Joma, 2010, pp.79, 84).

By involving all ages in my work as a co-ordinator, I highlighted a holistic perspective. It showed the Saami people's vulnerability, special needs, and distinct knowledge. Focus has been, and still often is, on the reindeer herders, leaving out men with no reindeers, the children, the women, the handicapped and other groups among the Saami. To work as Jonhild and I did makes it possible to empower the most vulnerable Saami through activities solely or partly designed to include them, and when possible, make them and their competence more visible to the local community. This is important to preserve and increase the status of Saami knowledge.

In my introduction, I cited Wilson and others who claim that sharing stories is healing and medicinal for the sharers. My intent was to show here that stories can help to improve the status of an underprivileged group through making public its neglected history. Stories bind people together as participants of the same common past. Stories from the past can explain cultural differences in another way and with a different authority than the modern Saami can. The stories can also provide explanations concerning why certain things are important for 
Saami today.

In the last decades, Indigenous people have criticized traditional Western research from within the academy. Indigenous scholars have claimed that researchers are biased, that they exclude the knowledge, history and experiences of Indigenous people for their own benefit, careers and power positions. In every research project, the researched - Indigenous people - should be included in the full process from beginning to end, including some follow-up afterwards to maintain good relations and provide important feedback. Indigenous researcher have also stated that their knowledge and cultural competence can be particularly beneficial because they will choose a methodology that is more compatible, ethically and politically, with the Indigenous people's cultures (Porsanger, 2004; Kuokkanen, 2008; Smith, 2012).

As I mentioned in the beginning, stories are well suited for Saami holistic epistemology. Stories show that there is knowledge among the Saami that their non-Saami neighbors are not always aware of and that is not always accessible to them. A common assumption is that old Saami traditions have diminished, but in this project we found that with the right competence, attitude and ethics, the worldview of the Saami people can be accessed, although rarely talked about. In particular, spiritual matters could be discussed and older beliefs could be determined, even though popular opinion, even expressed by some Saami themselves, claimed that religious beliefs had disappeared.

As Saami historically have had a marginal status because of colonization, their self-esteem is low. Although attitudes have changed in the last decades to the benefit of Indigenous peoples, there is trauma and distrust to be overcome. The work of increasing the status of the Saami will take time, and the risk is that traditional knowledge will be lost as the society as a whole is changing. But that makes Saami more receptive to documentation, in particular when they are involved in the whole process, hold positions of power, and can control access to The work with documentation is in itself strengthening for the south Saami people as a whole and functions as a resistance against assimilation. The storytellers help each other to remember and are proud of their skill and of being who they are - south Saami.

\section{About the Authors}

Åsa Virdi Kroik (corresponding author) is a 51-year-old South Saami woman born in a small village, Borgafjäll, on the Swedish side of Sápmi. For the last four years, she has been a PhD student in the history of religion in Uppsala University, Sweden. Her field of interest is Saami religion, power structures and different issues concerning the South Saami people. She is also focused on Indigenous methodologies and has analyzed the way field workers have developed their own version of Indigenous methodology in co-operation with the South Saami center Gaaltije. She is also a writer and has published four books, several articles, a children's book, 
and poetry. Before beginning her PhD studies, she worked in Röyrvik as a coordinator for Saami language and culture. Email: kroik@bahnhof.se

Jonhild Joma is a retired South Saami mid-wife. She was born in the area of Röyrvik in the Norwegian part of Sápmi and has spent most of her life there. All her life she has been active in Saami associations and cultural work and is well known for her knowledge of Saami traditions and language. For a long time she wanted to publish her knowledge about childbirth among elder South Saami and did so in a community-based project that I coordinated.

\section{References}

Åhrén, I. (2004). Frostviken - Lapparnas högkvarter. In Bergvall, \& P. Persson, Tidsspår. Västernorrlan - Sameland. Om samisk närvaro i Angermanland och Medelpad (pp. 61-90). Härnösand: Länsmuseet Västernorrland.

Bäckman, L. (2013). Studier i samisk religion. Stockholm: Stockholm University.

Bäckman, L. (2013). The Akkas. A study of four goddesses in the religion of the Saamis. In L. Bäckman, Studier i samisk religion (pp. 107-116). Stockholm: Stockholms universitet.

Dahl, G. (1940). Två år som indian. Stockholm: Natur och Kultur.

Darwin, C. (1859). On the origin of species. London.

Devy, G. N. (2011). A nomad called thief - reflections of Adivasi silence. New Delhi: Orient Black Swan.

Drake, S. (1979). Västerbottenslapparna under förra hälften av 1800-talet. Umeå: Två förläggare.

Dunfjeld-Aagård, L. (2007). Srsamiske kystområder: Et glemt kulturlandskap? i S. Lyngman, Foredrag fra seminar på Roros 2006 og Tronbeim 2007 (pp. 52-58). Snåsa: Stiftelsen Saemien Sijte.

Episkenew, J.-A. (2012 (2009)). Contemporary Indigenous Litteratures in Canada: heling from

Historical Trauma. i G. N. Devy, G. V. Davis, \& K. K. Chakravarty, Indigenity - Culture and Representation (ss. 75-86). New Delhi: Orient Black Swan.

group, F. (den 1303 2016). Nej till rasbiologiska bilder på lappar, halvlappar, tattare, zigenare ... Retrieved from https://www.facebook.com/groups/542498439165651/?fref=ts

Habel, Y. (2012). Rörelser och schatteringar inom kritiska vithetsstudier. In T. Hübinette, H.

Hörnfeldt, F. Farahani, \& R. Farahani, Om ras och vithet $i$ det samtida Sverige (pp. 45-82).

Botkyrka: Mångkulturellt centrum.

Hermanstrand, H. (2007). Om sørsamisk historie. In Lyngman, Foredrag fra seminar på Roros 2006 og Tronbeim 2007 (pp. 59-70). Snåsa: Stiftelsen Saemien Sijte.

Hermanstrand, H. (2010). Røyrvik Samene i Østre Namdal. Røyrvik: Røyrvik kommune.

Jernsletten, J. (2010). Gaelmieh i Njaarke. In A. V. Kroik, Där renflocken drar förbi (pp. 94-108).

Göteborg: Boska - Föreningen för bevarandet av samisk kultur och folkmedicin.

Joma, J. (2010). Berättelser om förlossningar. In Å. V. Kroik, Där renflocken drar förbi (pp. 74-85).

Göteborg: Boska - Föreningen för bevarande av samisk kulur och folkmedicin. 
Jürgensen, A., Svestad, A.-B. E., \& Fiskum, B. C. (2013). Teater som vertøy i en forsonende prosess Røyrvik kommune fra 2000 og inn i fremtiden. In T. Johnsen, \& L. M. Skum, Erkjenne fortid - forme framtid. Innspill til kirkelig forsoningsarbeid i Sápmi (pp. 93-107). Stamsund: Orkana forlag AS.

Kroik, Å. V. (2007). Hellre mista sitt huvud än lämna sin trumma. Hönö: Boska - Föreningen för bevarandet av samisk kultur och folkmedicin.

Kroik, Å. V. (2010). Namsvatnet - heligt vatten med samiskt namn? In Å. V. Kroik, Där renflocken drar förbi (pp. 66-73). Göteborg: Boska - Föreningen för bevarande av samisk kultur och folkmedicin.

Kuokkanen, R. (2008). Sami Higher Education and Research: Towards Building a Vision for Future. 1 H. Minde, Indigenous Peoples. Self-determination, Knowledge, Indigenity (pp. 267-286). Delft: Eburon Academic Publishers.

Lehtola, V.-P. (2004). The Sámi people. Traditions in transition. Inari: Kustannus-Puntsi Publisher.

Lundmark, L. (2004). Rasbiologin och samerna. In Bergvall, \& P. Persson, Tidsspår. Västernorrlan Sameland. Om samisk närvaro i Angermanland och Medelpad (pp. 91-108). Härnösand: Länsmuseet Västernorrland.

Mihesuah, D. A. (1998). Introduction. In D. A. Mihesuah, Natives and Americans Researching and Writing about American Indians (ss. 1-22). Lincoln \& London: University of Nebraska Press.

Porsanger, J. (2004). An essay about Indigenous methodology. Nordlit Special Issue on Northern Minorities, no. 15.

Rydving, H. (1993). The end of drum-time : Religious change among the Lule Saami, 1670s-1740s. Uppsala: Uppsala University.

Smith, T. L. (2012). Decolonizing methodology: Research and Indigenous peoples. London \& New York: Zed Books.

Svestad, A.-B. E. (2013). Kulturminnebasert verdiskapning - en balansegang mellom ulike intresser. Trondheim: Norges tekniske-naturvitenskaplige universitet NTNU.

Wilson, A. C. (1998). American Indian history or non-Indian perceptions of American Indian history? In A. Mihesuah (Ed), Natives and academics: Researching and writing about American Indians (pp. 23-26). Lincoln \& London: University of Nebrask Press.

Wilson, A. C. (1998). Grandmothers to granddaughter: Generations of oral history in a Dakota Family. In A. Mihesuah (Ed), Natives and academics: Researching and writing about American Indians (pp. 27-36). Lincoln \& London: University of Nebraska Press.

Zachrisson, I. (1997). Möten i Gränsland - Samer och germaner I Mellanskandinavien. Stockholm: Statens historiska museum. 